\title{
WYDZIAŁ TEOLOGICZNY AKADEMII KRAKOWSKIEJ MIĘDZY WIEKIEM ZŁOTYM A SASKĄ JESIENIĄ
}

„We wszystkim raczej innym kształciliśmy się niżeli w teologii. Była ona, jak pamiętasz, czerpana nie tyle ze źródeł, ile z potoczków, mało zaiste przejrzystych i wedle zdania wielu, dużo niosących z sobą nieczystości” — pisał po latach Andrzej Frycz Modrzewski do kolegi ze studiów odbywanych na krakowskim Wydziale artium pod koniec drugiej dekady XVI w. Opinia wielkiego erazmiańczyka rzeczywiście nie była odosobniona. Zabrakło już bowiem mistrzów tej miary, co Jan Elgot, Benedykt Hesse, Jakub z Paradyża, Tomasz ze Strzempina, których traktaty o naprawie Kościoła w dobie soboru bazylejskiego czytywała Europa. Ubywało studentów zagranicznych. Coraz mniej kształciło się szlachty. Akademia krakowska z międzynarodowej stawała się lokalną i plebejską. Dotyczyło to zwłaszcza Wydziału Teologicznego. Wśród wykładowców uczelni $15 \%$ pochodziło ze szlachty, tyleż wywodziło się z chłopów, a 70 \% z mieszczaństwa. Na Wydziale Sztuk Wyzwolonych, zwany wówczas filozoficznym, w pierwszej połowie XVI wieku zapisywało się rocznie około 150 studentów, z tego bakalaureat (odpowiednik matury) uzyskiwał tylko co trzeci, czwarty student, a do magisterium dochodziło jedynie 5-6\%. Na wyższych wydziałach, a wstęp do nich otwierało ukończenie sztuk wyzwolonych, a więc na medycynie, prawie, teologii studiowało niewielu. Stan źródeł nie pozwala na wszechstronne zestawienia liczbowe, ale i tu efektywność była niepozorna: w pierwszej połowie XVI wieku odbyło się na teologii około 30 promocji. Star-

* Poniższy tekst jest połączoną wersją dwóch wykładów, jakie zostały wygłoszone przez autora w katedrze wawelskiej dnia 11 stycznia 1991 i 1992 roku podczas uroczystego nabożeństwa profesorów, studentów i pracowników Papieskiej A kademii Teologicznej w Krakowie w rocznicę erekcji Wydziału Teologicznego na tutejszym Studium Generalnym (11 I 1397).

Podstawową literaturę do przedstawionej w artykule problematyki znajdzie Czytelnik w następujących opracowaniach: H. B a r y c z, Historia Uniwersytetu Jagiellońskiego w epoce humanizmu, Kraków 1935; Dzieje Uniwersytetu Jagiellońskiego w latach 1364-1764, red. K. L e p z z, t. 1, Kraków 1964; M. R e ch ow ic z, Sw. Jan Kanty i Benedykt Hesse w świetle krakowskiej kompilacji teologicznej z XV w., Lublin 1958; Dzieje teologii katolickiejw Polsce, red. M. Re ch ow icz, t. 2 cz. 1 - 2, Lublin 1975; Metryka promowanych Wydziału Teologicznego Uniwersytetu Krakowskiego z lat 1639-1741, wydał H. B a r y c z, "Nasza Przeszłość” 3:1947 s. 185-212; H. Kołł ą$\mathrm{t}$ a j, Stan oświecenia w Polsce w ostatnich latach panowania Augusta III (1750-1764), wyd. J. Hulewicz, Wrocław 1953. 
czyło ich prawie tylko do odnowienia kadr. W latach $1570-1603$ teologowie wypromowali sześć osób. Doktorów owych, łącznie z nostryfikacjami, było w okresie $1570-1628$ tylko jedenastu. Z owych utytułowanych zaledwie trzech odznaczyło się niejaką aktywnością pisarską. Pamiętajmy jednak, że w przejętej po średniowieczu tradycji szkolnej zwracano uwagę na dydaktykę, zostawiając twórczość własnej pilności wykładowcy.

Wydział się wyludniał. Odstręczał czas studiów, wynoszący $7-9$ lat i wysokie taksy promocyjne. Tym, co skracali sobie drogę do doktoratu uzyskując go latwiej za granicą, utrudniano nostryfikację. Zresztą stopnie miały realne znaczenie tylko w uczelni. Biskupstwa i kanonie (prócz 4 doktorskich na 36 w Krakowie) zastrzeżone były dla szlachty. Nie Wydział Teologiczny ani duszpasterzowanie, ale dobre urodzenie, praca w kancelarii królewskiej i monarsze względy współgrały w kreowaniu składu episkopatu. Na 29 biskupów polskich, mianowanych w latach $1598-1615$, tylko jeden miał jakiś stopień z teologii, a dwóch - z prawa. Ale nie tylko stopnie akademickie świadczyły o znajomości teologii, a jej uprawianie nie stanowiło wyłącznie domeny profesorów. Inaczej nie byłoby pisarstwa Stanisława Hozjusza, Marcina Kromera, Andrzeja Nideckiego, Marcina Białobrzeskiego, biskupów, którzy nie mieli studiów teologicznych, ani nie byli profesorami, podobnie jak nie byli nimi Stanisław Orzechowski, Hieronim Powodowski czy - nie licząc Wydziału Sztuk - Stanisław Sokołowski; ale dzięki znakomitej formacji humanistycznej i sporemu oczytaniu w teologii oraz zdolnościom i pracowitości, znaczą razem więcej w dziejach polskiej myśli teologicznej niż współczesny im wydział tej scencji w Krakowie in corpore.

Powodów było sporo. Stan uposażenia wpływał na to, że pracownicy każdegọ wydziału imali się dodatkowych zajęć. Uczyli prywatnie, pisywali po kancelariach, fabrykowali panegiryki, medycy i juryści brali praktykę albo przyjmowali święcenia i wespół z teologami chwytali kościelne stanowiska i beneficja. Niektórzy w ogóle porzucali Akademię, filozofowie zaś, szczególnie chudo uposażeni, starali się przenieść na inne fakultety, zwłaszcza teologiczny, dysponujący najlepszymi prebendami. Osiągali je przeważnie późno, nie bez emulacji, uzyskując magisterium teologii po długich studiach, najczęściej między 40 a 50 rokiem życia. Taka droga awansu, wieńczonego daleko za połową życia dożywotnim dostatkiem (świadczą o tym hojne legaty, często na rzecz Akademii), nie sprzyjała ani specjalizacji, ani, przynajmniej w kraju, twórczości. Jej brak lub nikłe znaczenie, a także słabnący napływ studentów, czyli znamiona upadku Akademii, wspólne dla europejskich uniwersytetów doby renesansu, miały przecież bardziej podstawową przyczynę. Uczelnie nie nadążały za przemianami społecznymi i ideowymi. Humanizm, główny nurt życia umysłowego epoki, docierał wprawdzie do szacownych murów, ale nie mieścił się już w tradycyjnych strukturach i programach edukacji. Słuchacze skupiali się 
wokół uznanych nauczycieli nowej myśli nierzadko poza salami wykładowymi. Resztę niósł wynaleziony niedawno druk, poszerzając krąg adeptów.

W Krakowie humanizm przenikał także na wszystkie wydziały, lecz związał się przede wszystkim ze sztukami wyzwolonymi. Biskup krakowski Piotr Tomicki, utrzymujący kontakt z Erazmem, widział w humanizmie nową formę kultury, w której upowszechnieniu istotną rolę odegrać miała Akademia. Bowiem już synod piotrkowski, zwołany w 1510 r. przez prymasa Jana Łaskiego, zlecił episkopatowi reformę Uniwersytetu, a zwłaszcza Wydziału Teologicznego, aby mógł się przeciwstawić narastającej krytyce Kościoła. Dzięki mecenatowi Tomickiego oraz jego poprzednika Jana Konarskiego, a także biskupów Jana Dantyszka, Andrzeja Krzyckiego, Jana Lubrańskiego, Macieja Drzewickiego, zatrudniono w jagiellońskiej wszechnicy kilku cudzoziemców i Polaków, wybitnych wykładowców, zwłaszcza retoryki. To ci mistrzowie, wędrowni humaniści, niesforna cyganeria intelektualna, wrażliwi przecież na głosy czasu, wykładający także prywatnie, przyciągali młodzież. Spośród ich słuchaczy wywodziła się znaczna część polskiej elity politycznej i umysłowej Wieku Złotego. Rej, Kochanowski, Modrzewski, Orzechowski, Kromer, Górski, Karnkowski, Hozjusz, Herbest nie szukali w Krakowie, a następnie we Włoszech czy Niemczech, gdzie uzupełniali studia, naukowych stopni, ale ogólnej kultury humanistycznej. Dzięki niej potrafili potem kłaść samodzielnie zręby kultury narodowej. To, co zawdzięczali Akademii Krakowskiej, powstawało i tu niejako na obrzeżu starzejącego się modelu jej oficjalnej działalności.

$\mathrm{O}$ zwycięstwie kierunków tradycyjnych i scholastycznych w latach trzydziestych i czterdziestych XVI wieku zdecydował głównie upór Wydziału Teologicznego. Nieufność do nowości znalazła swój żelazny argument w tym, że część humanistów skłaniała się ku reformacji. Inni, jak choćby Hozjusz, który jeszcze w 1530 r. ostro krytykował centralizm kurii rzymskiej, opowiedzieli się jednoznacznie po stronie katolickiej. Przywiązani do scholastyki profesorowie woleli jednak dostrzegać nurt radykalny, by odciąć się od humanizmu. I tu było sedno wewnętrznego kryzysu. Akademickimi teologami zostawali wprawdzie ludzie, którzy kształcili się, a potem również podczas swych studiów teologicznych wykładali na humanistycznym Wydziale Sztuk Wyzwolonych. Owszem, niektórzy z nich, jak Wojciech z Nowego Pola, Jan z Oświęcimia, Marcin Glicjusz, Jan Leopolita czy Walenty Wróbel byli zwolennikami humanistycznych prądów. Ale większość, wtapiając się pojedynczo w grono teologów, przywiązanych do zakrzepłych i powtarzanych formuł, do spekulacji i symbolizmu, nie znajdowała tu naukowych instrumentów, potrzebnych do podjęcia dyskusji z protestantyzmem. Ruch nowatorski sięgał bowiem do zaniedbanych w scholastyce badań biblijnych i historycznych. Nadto - jak pisał bp Rechowicz „do polemiki tej nie zachęcały liczne dekrety administracyjne i stosowanie środków tak zawodnych, jak np. składanie wyznania wiary, rewizje, potępienia czy usuwanie z katedr osób podejrzanych”. Inercję oraz inne grzechy za- 
niedbania oceniano wówczas znacznie łagodniej niż nie mieszczącą się w szeregu samodzielność, której racje uznawali potomni, chociaż czasem już współcześni. Humanista i prawnik Stanisław Hozjusz mógł napisać swą wspaniałą Confessio właśnie dlatego, że w Krakowie nie studiował teologii i nie został wciągnięty w scholastyczne schematy, ale czytywał Ojców Kościoła, literaturę teologiczną hiszpańskiego i niderlandzkiego Odrodzenia i orientował się tak w twórczości katolickiej, jak protestanckiej. Owszem, paru profesorów Akademii, jak Antoni z Napachania, Jakub Górski starszy czy Stanisław Sokołowski włączyło się w kontrowersje z innowiercami. Zapewne stać było na to jeszcze kilku, ale zajęli się akurat walką z najważniejszymi adwersarzami protestantów, czyli jezuitami.

Uczelnia chciała zachować swój oświatowy monopol, ojcom Societatis zależało niezwykle na utworzeniu szkół publicznych w stolicy, a nawet na opanowaniu katedr Akademii. Koniec XVI oraz trzy dekady XVII w. stały pod znakiem walki profesorów z jezuitami. Towarzystwo uzyskało poparcie nuncjusza i Zygmunta III, uniwersytet odwoływał się do niechętnej zakonowi opinii szlachty i duchowieństwa. Bp Myszkowski brał stronę Akademii; Szyszkowski jezuitów. Wzajemne nadużywanie ambony, pozwy sądowe, intrygi i pamflety pustoszyły całe pole wartości chrześcijańskich. W ostatniej fazie sporu nie obyło się nawet bez tumultów i bójek między słuchaczami uniwersytetu oraz jezuickiego kolegium, które po 10 latach burzliwego istnienia zakonnicy musieli zamknąć w wyniku zdecydowanej postawy Władysława IV. Król uzyskał w 1634 r. od papieża Urbana VIII zakaz prowadzenia przez jezuitów szkolnictwa wyższego w Krakowie. Ogólny nadzór nad wychowaniem narodowym pozostał w rękach Akademii, której monopol wyższego nauczania zatwierdziła konstytucja sejmowa w 1635 r. Gdy Jan Kazimierz podniósł jezuickie kolegium we Lwowie w $1661 \mathrm{r}$. do rangi uniwersytetu, sejm uwzględnił protest Akademii Krakowskiej i decyzji tej nie zatwierdził. Zmienne jednak stanowisko królów i biskupów krakowskich ułatwiało lub utrudniało Akademii utrzymanie swojej pozycji w szkolnictwie. Za biskupów Gembickiego i Trzebickiego dochodziło też do napięć na tle kompetencji profesorów i wielkiego kanclerza. Skłóceni uczniowie jezuitów i żacy tak samo jednak napadali na świątynie, domy i pogrzeby krakowskich kalwinów i arian, doznając niemałej pobłażliwości zarówno ze strony władz Akademii, jak Towarzystwa.

Jezuici urządzali wielkie uroczystości w związku z kanonizacją swoich świętych, akademikom zaś zarzucali niedostatek pobożności, tudzież reformacyjne tradycje. Odpowiedzią był wzrost praktyk religijnych studenckich bractw oraz szerzenie kultu Jana Kantego. Co do różnic merytorycznych — jezuici, w przeciwieństwie do uniwersytetu, ciągle modernizowali programy swych szkół. Na filozofii zarzucili scholastyczne spekulacje, uczyli starannie łaciny, retoryki i matematyki, czyli umiejętności wielce przydatnych szlacheckim i mieszczańskim synom. W wykładach $\mathrm{z}$ teologii, zgodnie $\mathrm{z}$ trydenckimi wymaganiami, 
zwrócili uwagę na praktyczny kurs teologii moralnej oraz na polemikę z protestantyzmem. „Akademia Krakowska pod tym względem bynajmniej nie znajdowała się w awangardzie. Jeśli jezuici trafiali do ludzi oświeconych i wśród nich zdobywali zwolenników, to nie apriorystyczna niechęć do Akademii, ale zalety programowe szkół zakonnych oraz ich użyteczność decydowały o zajmowanych pozycjach" (M. Rechowicz). Uniwersyteccy mistrzowie filozofii i teologii pojęli wreszcie, że ze szkolnictwem jezuickim nie da się walczyć bez zmodernizowania własnego nauczania. Podjęli zatem reformę i oparli wykład podstawowy na Summie św. Tomasza w miejsce Sentencji Piotra Lombarda. Był to rok 1604.

Druga połowa XVII i pierwsza XVIII w. nie były czasem rozkwitu Akademii Krakowskiej, ani jej Wydziału Teologicznego. Przyroda i bieg wydarzeń politycznych zagrażały nie tylko nauce. Zaraza dziesiątkowała mieszkańców Krakowa w 1622 i 1652/3 r., kiedy zmarło także kilku profesorów. Wkrótce pojawili się Szwedzi — była okupacja, grabież, kontrybucje. Nastąpił potem czas odbudowy, przecięty znów pasmem czarnej śmierci w latach $1677-1680$. W okresie $1702-1705$ miasto wydzierali sobie na przemian a zbrojnie Szwedzi, Sasi, Rosjanie, Polacy. Przez kilka lat, do 1710 r., grasowała dżuma, zagarniając ponad 7 tysięcy krakowian. Po tych wydarzeniach pozostanie Kraków 10-tysięcznym miastem rozsypujących się kamienic. Gdy ginęli ludzie, nie działały szkoły i rozgrabiano mienie, nie mogły kwitnąć nauki. Inter arma... Ustępowało przecież kiedyś morowe powietrze i powracał czas pracom akademickim sprzyjający. Po wiekach, gdy głosy mistrzów dawno przebrzmiały, pytamy najpierw o księgi.

Po większości profesorów zachowało się tylko po kilka, drukowanych na 2-4 kartach, kwestii, stanowiących rodzaj konspektów przeprowadzonej dysputy. Przykładem może być ceniony mistrz, wielokrotny dziekan Wydziału, Marcin Wadowita (†1641), w którego wydanym dorobku znalazło się tylko 9 takich druczków. Często bibliografia typowego teologa akademickiego zawiera, oprócz takich skrótów, parę kazań, kilka panegiryków, kalendarze lub prace z geometrii, logiki, astronomii czy innych sztuk wyzwolonych. Tak było i w przypadku, cieszących się opinią dobrych teologów, Stanisława Jurkowskiego $(\dagger 1669)$, Sebastiana Stryjewicza $(\dagger 1681)$ czy Krzysztofa Sowińskiego $(\dagger$ 1699). Podobnie u twórców paru poważniejszych prac teologicznych, jak Adam z Opatowa († 1647) czy Szymon Makowski (†1683). Skąd ta różnorodność zainteresowań?

Statystyczny akademik przechodził z Wydziału Filozoficznego na Teologiczny licząc lat 45. Wykładał odtąd kurs dogmatyki, teologii moralnej, sakramentologii; odbywał dysputy, zostawał licencjatem, wreszcie po około 10 latach profesury (profesorów było średnio 12) uzyskiwał doktorat w połowie szóstego krzyżyka. Ówczesnych to nie dziwiło. Układ szczebli akademickich awansów z góry wykluczał specjalizację. Akademik miał być uniwersalnym 
nauczycielem i dyskutantem. Pisarstwo nie wynikało z jego profesji, ale stanowiło sprawę prywatną, jak dziś w przypadku nauczyciela szkoły średniej lub duszpasterza. Profesor miał być gramatykiem, poetą, rektorem, logikiem, fizykiem, metafizykiem i teologiem we wszystkich dziedzinach. Aż do reformy Kołłątaja Akademia pozostawała uczelnią średniowieczną, czyli miała przekazywać sumę ustalonej wiedzy, nie zaś stawiać sobie cele naukowo-badawcze. Ideałem akademika był człowiek mogący dysputować na wszelkie poznawcze tematy - in omni scibili. O stopniach i posuwaniu się na stanowiskach decydowała nie twórczość, ale słuchanie i prowadzenie wykładów oraz odbywanie dysput.

Te cotygodniowe dyskusje, polegające na bronieniu lub atakowaniu tez, stanowiły niezłe ćwiczenie sprawności umysłowej (dziś nam tego brakuje). Skutki takiego trenowania intelektu nie groziły wprawdzie zamknięciem go w jednej dyscyplinie; przeciwnie a gorzej - rozpraszeniem sił w dożywotnim wieloboju poznawczym. Tego wszakże — z racji postawy wyraźnie odtwórczej - nie należy kojarzyć z dynamiką renesansowej wszechstronności. Uboczny skutek owej profesorskiej niepiśmienności był taki, że z reguły trudno jest ocenić, co naprawdę umieli.

A rękopisy? Z XVII - XVIII w. pozostało ich niewiele, a archiwum Wydziału ocalało w formie szczątkowej. Stąd nawet ilość studentów i programy nauczania dają się odtworzyć jedynie ze sporymi lukami. Lepiej znamy tych, co uzyskali stopnie, a to dzięki zachowaniu się metryki bakałarzy i doktorów teologii, prowadzonej w latach $1639-1741$. W okresie tym promowano 28 bakałarzy i tyluż doktorów oraz nostryfikowano 48 dyplomów zagranicznych. Ponad połowę spośród tych 76 doktorów (40) stanowili tzw. extranei, nie pozostający na Wydziale. Najczęściej (28 osób) byli to księża diecezjalni, przeważnie kanonicy poznańscy i włocławscy. Ilość tych promocji spoza Wydziału, przeprowadzanych bez ukończenia całego kursu teologii, nasila się po $1690 \mathrm{r}$. Zwyczaj przejęto prawdopodobnie z Padwy, Bolonii i Rzymu, gdzie odróżniano dwie kategorie doktoratów: zwykłe, bez prawa do nauczania, oraz te, które dawały ius collegii. Od uzyskujących te pierwsze, nieprofesjonalistów, wymagano na egzaminie o wiele mniej.

Owych wyedukowanych oraz poduczonych doktorów teologii kreowano w Akademii łącznie — jak wspomniano - 28 (i tyluż bakałarzy) za 102 lata. Wydajność tedy fakultetu, mierzona uzyskiwanymi stopniami, wynosiła dwóch bakałarzy i dwóch doktorów (,większych” czy „mniejszych”) na 7 lat (żeby nie rzec - 0,2 doktora i tyleż bakałarza rocznie). Przygnębiającą statystykę ratują nieco ci, co dłużej czy krócej kształcili się na Wydziale, nie uzyskując stopni. Wizytacja Załuskiego z 1748 r. pozwala wydobyć dane o wykształceniu w przypadku 124 plebanów z terenu dzisiejszej archidiecezji krakowskiej. Okazuje się, że teologię w seminarium poznawało $39 \%$ tych księży, w Akademii Krakowskiej — 34 \%, w obu tych szkołach — 14, w żadnej — 13 . 
Zatem niemal co drugi ksiądz święcony w 1. połowie XVIII w. zetknąłby się $\mathrm{z}$ Wydziałem, z tym że nie wiadomo jak długo. Znany jest czas pobytu w seminarium dla 41 osób z tej grupy: najczęściej $1-2$ lata, ale także parę miesięcy lub 3 lata. Seminarzyści nie uczęszczali na Wydział, ale - jak wskazują poszczególne przypadki - czas pobytu w seminarium nie zawsze był odwrotnie proporcjonalny do spędzonego na Wydziale. W 1758 r. bp Załuski utworzył w Krakowie osobne, trzecie po zamkowym (erygowane w 1601 r.) i stradomskim (1732), seminarium akademickie, w przeciwieństwie do poprzednich, statutowo związane z Wydziałem. W ten sposób lokalnie naprawiano historyczne zaniedbanie. Potrydenckich seminariów nie łączono bowiem w ogóle z miejscowymi wydziałami teologicznymi.

Wiele uwagi, sił i środków Akademii absorbowała sprawa beatyfikacji (1680 r.), a następnie starania o kanonizację Jana z Kęt. Profesorom, rzadko pisującym własne rozprawy teologiczne, marzył się tytuł doktora Kościoła dla swego patrona. Podjęto prace nad odczytaniem ciężkiej kursywy gotyckiej i dokonaniem dla potrzeb procesu kopii pism błogosławionego. Badanie poprawności doktrynalnej tekstu w Kongregacji Obrzędów ujawniło w 1703 r. koncyliarystyczne treści, obecne w kopii obszernego Janowego komentarza do św. Mateusza. Krakowscy mistrzowie, bojący się utrącenia swych dążeń, „wysunęli fantastyczną hipotezę, że współcześnie istniało dwóch Janów z Kęt, z których pierwszy był świętym, drugi koncyliarystą" (M. Rechowicz). Parcelowanie dzieła między nich, gromadzenie w tym celu argumentów i opinii paleografów absorbowały uwagę, pochłaniały czas (kanonizacja - 1767) i pieniądze (Kołłątaj szacuje koszta tego etapu na 300 tys. zl), których często brakowało na bardziej podstawowe cele.

Twórcami staropolskiej teologii — sprawdzalnej, bo drukowanej — byli przede wszystkim zakonnicy. Jeśli ponad dwa tysiące nazwisk ze Słownika polskich teologów katolickich (pod. red. H. E. Wyczawskiego, t. 1 - 4, Warszawa 1981 - 1983) zestawić według półwieczy, w których powstała większa część twórczości poszczególnych osób, to okaże się, że w 2. połowie XVI w. spotkamy tu 52 księży diecezjalnych i 41 zakonnych, w 1 . połowie XVIII w. odpowiednio - 85 i 171, w tym 72 jezuitów i 44 dominikanów. Proporcje te utrzymają się i w dwu następnych półwieczach, przy ogólnym spadku ilości teologów o $1 / 5$, co ilustruje poniższa tabela.

Wymowę powyższego zestawienia osłabia nieporównywalność osób: twórca licznych a obszernych dysertacji liczy się tak, jak i posiadacz dorobku mieszczącego się na połowie arkusza druku. Samodzielność, przyczynkarstwo i wtórna myśl ważą wśród liczb tak samo, nie pracujący zaś piórem i nie drukowani przepadają w statystyce, nawet gdyby byli niezrównanymi dydaktykami. Wyrywkowa nawet znajomość tych person potwierdza domniemanie, iżżadna wyliczona wyżej grupa nie składała się wyłącznie z wielkich lub pomniejszych czy też prawie żadnych teologów. Liczby z tabeli mają tedy swoją wymowę i każą 
AUTORZY PUBLIKACJI TEOLOGICZNYCH W POLSCE XVI - XIX W.

\begin{tabular}{|l|rr|rr|rr|rr|rr|}
\hline \multicolumn{1}{|c|}{ wiek } & \multicolumn{2}{c|}{ XV } & \multicolumn{2}{c|}{ XVI } & \multicolumn{2}{c|}{ XVII } & \multicolumn{2}{c|}{ XVIII } & \multicolumn{2}{c|}{ XIX } \\
\multicolumn{1}{|c}{ polowa } & 1. & 2. & 1. & 2. & 1. & 2. & 1. & 2 & 1. & 2 \\
\hline Kler diecezjalny & 42 & 24 & 32 & 52 & 85 & 76 & 58 & 111 & 101 & 102 \\
Zakony: jezuici & & & 3 & 27 & 72 & 68 & 70 & 68 & 10 & 19 \\
$\quad$ dominikanie & 4 & 3 & 3 & 9 & 44 & 26 & 13 & 13 & 7 & 7 \\
bernardyni & & 2 & 7 & 2 & 32 & 11 & 6 & 12 & 2 & 3 \\
pijarzy & & & & & & 5 & 5 & 31 & 13 & 9 \\
paulini & & & 1 & 1 & 10 & 8 & 18 & 16 & 3 & 1 \\
franciszkanie & 2 & & 1 & 2 & 13 & 3 & 12 & 16 & 1 & 1 \\
reformaci & & & & & & 8 & 10 & 15 & 5 & 5 \\
misjonarze & & & & & & & 2 & 5 & 12 & 6 \\
\hline
\end{tabular}

się zastanowić nad miejscem krakowskiego Wydziału Teologicznego w polskiej historii tej dyscypliny.

Oczywiście, profesorów było w ogóle niewielu (nie oni przecież sami wypełniają poczet księży diecezjalnych, uprawiających teologię pisemnie) w stosunku do ilości zakonników. Jakościową rangę owych dokonań także można przybliżyć, zestawiając orientacyjnie objętość tekstów, jakie w Dziejach teologii katolickiej w Polsce (t. 2 cz. 1 -2) dla okresu staropolskiego poświęcono akademickim i pozostałym teologom. Proporcje wykażą niejakie powinowactwo z układem powyższej tabeli. Dobra teologia w gruncie rzeczy nigdy przecież nie dzieliła się na akademicką i jezuicką czy jakąkolwiek, według uprawiających ją środowisk, monopoli i tytułów.

\author{
DIE THEOLOGISCHE FAKULTÄT DER KRAKAUER AKADEMIE \\ ZWISCHEN DEM GOLDENEN ZEITALTER UND DEM SÄCHSISCHEN HERBST
}

\title{
Zusammenfassung
}

Die Lage der Fakultät stellen zuerst folgende Zahlen dar: eine kleine Studentenzahl und 30 Promotionen in der 1. Hälfte des 16. Jh., und in den Jahren 1570 - 1628 lediglich 17 Promotionen, einschließlich Nostrifikationen. In den Jahren 1639-1741 wurden 28 Bakalareustitel und 28 Doktorwürden verliehen, 48 ausländische Diplome wurden anerkannt. Nur professionelle Promotionen, die das Recht auf das Unterrichten (ius collegii) gaben, wurden mit Einhaltung vollkommener Anforderungen an das Studium und die Prüfung durchgeführt.

Lange Studiendauer ( 7 - 9 Jahre), hohe Promotionsgebühren und geringe soziale Bedeutung akademischer Grade haben dabei eine abschreckende Rolle gespielt. Kirchliche Stellen (Bischöfe, Kanoniker) waren seit Ende des 15. Jh. für Adlige verbehalten, und für die kirchliche Laufbahn zählten mehr Jura- als Theologiekenntnisse. Die Akademie von internationaler Bedeutung wurde im 16. Jh. immer mehr regional und plebejisch (nur $15 \%$ der Professoren waren adliger Herkunft). Der Humanismus verbreitete sich vor allem an der Fakultät artium, in Theologie herrschte 
traditionell die Scholastik. Die theologischen Werke, im alten und neuen Stil, entstanden vor allem außerhalb der Akademie (hauptsächlich von Jesuiten verfaßt). Der Magistertitel in Theologie wurde meistens zwischen dem 40. und 50. Lebensjahr verliehen. Die Theologische Fakultät war am besten ausgestattet und stellte den Gipfel der Universitätsbeförderung dar. Das Fehlen einer Spezialisierung hat eine selbständige wissenschaftliche Tätigkeit auch nicht unterstützt. Die war eine private Angelegenheit, und ein seit Mittelalter angestrebtes Vorbild eines Akademikers war ein Mensch, von dem man Didaktik erwartete und die Fähigkeit, über alle Erkenntnisfragen zu diskutieren. Im 17. Jh. setzte die Akademie viel Kraft in den Kampf gegen die Jesuiten für die Verteidigung ihres Monopols auf höheres Unterrichten ein. Viel Zeit und Mittel kosteten auch lange Bemühungen um die Seligsprechung (1680) und Meiligsprechung (1767) des Professors der Akademie Joannes Cantius $(\dagger 1473)$.

Der Einfluß der Fakultät auf die Ausbildung des geistlichen Standes war jedoch wesentlich größer, als das wegen all dieser Beschränkungen zu erwarten wäre. Eine Besichtigung der Krakauer Diozöse Mitte des 18. Jh. hat ergeben, daß fast die Hälfte der Pfarrer vor Priesterweihe länger oder kürzer Theologie an der Fakultät studiert hat. 